\title{
Review Article \\ Chewing and Attention: A Positive Effect on Sustained Attention
}

\author{
Yoshiyuki Hirano $^{1,2}$ and Minoru Onozuka ${ }^{3}$ \\ ${ }^{1}$ Research Center for Child Mental Development, Graduate School of Medicine, Chiba University, 1-8-1 Inohana, Chuo-ku, \\ Chiba 260-8670, Japan \\ ${ }^{2}$ Research Program for Carbon Ion Therapy and Diagnostic Imaging Research, Center for Charged Particle Therapy, \\ National Institute of Radiological Sciences, 4-9-1 Anagawa, Inage-ku, Chiba 263-8555, Japan \\ ${ }^{3}$ Department of Judo Therapy and Medical Science, Nippon Sport Science University, 7-1-1 Fukuzawa, Setagaya-ku, \\ Tokyo 158-8508, Japan \\ Correspondence should be addressed to Yoshiyuki Hirano; hirano@chiba-u.jp
}

Received 12 August 2014; Accepted 2 October 2014

Academic Editor: Huayue Chen

Copyright (C) 2015 Y. Hirano and M. Onozuka. This is an open access article distributed under the Creative Commons Attribution License, which permits unrestricted use, distribution, and reproduction in any medium, provided the original work is properly cited.

\begin{abstract}
Chewing is crushing food not only to aid swallowing and digestion, but also to help stress relief and regulate cognitive function, especially in attention. It is well known that chewing gum is used for sleepiness prevention during work, learning, and driving, suggesting a link between chewing and sustained attention. We hypothesized that chewing elevates attention and/or alertness, leading to improvements in cognitive performance. We carried out a systematic review of the PubMed database. We inspected the attributes of effects on attention in studies investigating the effects of chewing on attention or alertness conducted with prepost design in healthy subjects, except elderly. We identified 151 references, 22 of which were included: 14 (64\%) showed positive attributes of effects on attention, 1 (5\%) showed negative attributes of effects on attention, $5(23 \%)$ showed both positive and negative attributes of effects on attention, and $2(9 \%)$ showed no significant attributes of effects on attention. Thus, positive attributes of effects of chewing on attention, especially on sustained attention, were shown in over half of the reports. These effects also appeared with improvement in mood and stress relief and were influenced by time-on-task effect. Further studies are needed, but chewing could be useful for modifying cognitive function.
\end{abstract}

\section{Introduction}

The most dominant function of chewing (or mastication) is thought to be crushing of food to aid swallowing and digestion. Besides this essential role, recent studies have mentioned a unique function that affects brain function. For example, bruxism, which is involuntary grinding of teeth typically during sleep, is thought to be caused by psychological stress [1,2]. Furthermore, chewing gum is used for maintaining alertness and avoiding sleepiness while operating a vehicle or studying. Also, adverse oral health such as periodontitis [3] and tooth loss [4] may be a risk factor of cognitive decline in elderly. These findings support the concept that chewing is strongly associated with cognitive function such as learning and memory and keeping and increasing attention [5].

This relationship between chewing and cognitive functions was empirically estimated a long time ago. In 1939,
Hollingworth [6] reported that chewing increased relaxation and the performance of cognitive function like numberchecking and typing. This relaxation effect was investigated by means of electroencephalography (EEG), and regular gum chewing was shown to increase alpha power after chewing compared with control at almost all positions [7]. After that, additional EEG experiments were conducted under conditions of chewing gum with flavor or almost no taste and odor $[8,9]$. The results showed that alpha and beta activity patterns were not consistent, although chewing flavored gum consistently increased beta activity and induced arousal effects. Thereafter, more than twenty studies investigated the effects of chewing on cognitive function using modern neuropsychological testing, the first one being carried out by Wilkinson et al. in 2002 [10]. They reported improvement of performance of episodic memory and spatial and numeric working memory in the chewing group. 
However, no improvement was observed in attention. After that, Tucha et al. [11] presented controversial results in their replication study. They reported that chewing increased sustained attention, although no beneficial effect was found on memory, and there were aversive effects on alertness and flexibility. Since those studies, the issue concerning the existence and attributes of effects of chewing has remained a subject of discussion up to the present. Later on, several studies investigated the relationship between chewing and cognitive functions using functional magnetic resonance imaging (fMRI) and EEG [12-15] to elucidate the mechanisms of these effects. However, the reported effects of chewing on cognitive functions have been rather inconsistent and have still not been fully clarified. With regard to the results, we hypothesized that chewing affects attention and/or alertness, consequently leading to improvements of cognitive performance. Therefore, we reviewed the literature in respect to the effects of chewing on aspects of attention, and we discussed the existence and attributes of these effects.

\section{Methods}

2.1. Search Strategy. A systematic search strategy was used to identify appropriate publications. We conducted online search at the PubMed online database using the terms (chewing OR mastication) AND (attention OR alertness OR cognitive) NOT ("oral health" OR review OR elderly OR disorders) on August 5th, 2014, with no time span specified for publication date. A total of 151 hits came back.

\subsection{Selection Criteria. Studies were included if they met} the following criteria: (i) reported in an original paper, (ii) examined the effect of chewing in healthy children or adults, but not in the elderly, to rule out the possible influence of oral health and cognitive impairments, (iii) evaluated the efficacy of attention, including alertness, vigilance, executive control, and reaction time, compared with no gum chewing conditions, and (iv) written in English. After applying these selection criteria, 22 papers were included in the current review.

2.3. Variables of Interest. The following variables were examined for each article included in the review: (i) cognitive tests and psychological rating scales, if applicable, (ii) chewing objects, (iii) summary of results compared with nonchewing condition unless stated, and (iv) attributes of effects on attention.

\section{Results and Discussion}

The 22 articles were checked for cognitive tests and psychological rating scales, chewing objects, summary of results, and attributes of effects on attention (see Table 1). First, we focused on the most interesting variable, the attributes of effects on attention, categorizing them by the direction of effects. As shown in Table 1, more than half of the reports indicated positive attributes of effects on attention, with $14(64 \%)$ showing positive (at least somewhat), 1 (5\%) showing negative, 5 (23\%) showing both positive and negative attributes of effects on attention, and 2 (9\%) showing no significance. The appearance of reports presenting negative attributes showed a decreasing trend with recent experimental conditions. Next, we discussed the factors of mood and time-on-task effects on the results according to the summaries of results in order to understand the mechanisms.

With regard to mood, Smith [16] examined memory, intelligence test, alertness, and mood in a single study. He reported that alertness and hedonic tone in addition to intelligence test were improved, although memory showed no improvement. The following study by Smith [17] added improved selective and sustained attentions while the hedonic tone benefit had disappeared. Also, increased pretest alertness and hedonic tone and reduced posttest anxiety in mood were indicated, but without benefit for attention in another report by Smith [18]. He mentioned that two types of mechanisms were activated by chewing [16]. One was related to the mobilization of energetic resources, in particular facial muscles [19], and another was related to neurotransmitter function, specifically the 5-HT descending inhibitory pathway [20]. Scholey et al. [21] reported that chewing induced better performance on the test battery requiring memory and attention, with increased alertness and reduced state anxiety, stress, and saliva cortisol. They speculated that the mechanism of cognitive performance enhancement was secondarily induced by relief of mental stress [22], in addition to increased heart rate [10], cerebral blood flow [23], and brain activity [24] due to chewing. Thereafter, antistress effects were not replicated, but increased alertness was observed following the cognitive stressor test [25] and acute social stress test [26], which was suspected to be induced by greater cerebral activity following the chewing of gum [27]. Sakamoto et al. [14, 15] have reported the influences of chewing on the central nervous system by measuring reaction time (RT) and event-related potentials (ERPs). They suggested that chewing affects the state of arousal via the ascending reticular activating system, and this accelerates cognitive processing. More recently, Johnson et al. [28] found improvement in sustained attention covaried with subjective alertness, strongly supporting the hypothesis that chewing elevates attention and/or alertness, consequently leading to improvements in cognitive performance.

Another factor, the time-on-task effect in relation to the effect of chewing on attention, was discussed. Tucha and Simpson [29] proposed that time is an important factor in the psychodynamics of gum chewing. They put forward this new idea that it is one of the reasons for the difficulties in replicating the results of studies, in addition to the brand of gum, familiarity with gum, the experimental design, and statistical analysis. Tänzer et al. [30] examined the concentration performance in 8-9-year-old children using a 16minute test. For the first 12 minutes, classes who did not chew gum performed better but were then overtaken by classes chewing gum, showing the interaction between chewing condition and time. After that, Allen and Smith [31] examined the time-on-task effect within each individual performance task, confirming this effect on vigilance reaction time. More recently, Morgan et al. [32] also reported that correct reaction 
TABLE 1: Studies on the effects of chewing on attention.

\begin{tabular}{|c|c|c|c|c|}
\hline Study & $\begin{array}{l}\text { Cognitive tests } \\
\text { and psychological } \\
\text { rating scales }\end{array}$ & Chewing objects & $\begin{array}{l}\text { Summary of results (compared with nonchewing } \\
\text { condition unless stated) }\end{array}$ & $\begin{array}{l}\text { Attributes of effects } \\
\text { on attention }\end{array}$ \\
\hline $\begin{array}{l}\text { Wilkinson et } \\
\text { al. (2002) [10] }\end{array}$ & $\begin{array}{l}15 \text { tests on } \\
\text { memory and } \\
\text { attention }\end{array}$ & $\begin{array}{l}\text { Sugar-free } \\
\text { spearmint gum }\end{array}$ & $\begin{array}{l}\text { Improvements of scores on episode and working } \\
\text { memory and simple reaction time. Elevation of heart } \\
\text { rate. No significant differences in attention. }\end{array}$ & Not significant \\
\hline $\begin{array}{l}\text { Tucha et al. } \\
\text { (2004) [11] }\end{array}$ & $\begin{array}{l}12 \text { tests on } \\
\text { memory and } \\
\text { attention }\end{array}$ & $\begin{array}{l}\text { Sugar-free } \\
\text { spearmint gum and } \\
\text { sugar-free tasteless } \\
\text { gum }\end{array}$ & $\begin{array}{l}\text { Shortening of reaction time on sustained attention, } \\
\text { prolongation of reaction time on alertness, and increase } \\
\text { of number of errors on flexibility. No significant } \\
\text { differences in memory and pulse rate. }\end{array}$ & $\begin{array}{l}\text { Positive or negative } \\
\text { depending on task }\end{array}$ \\
\hline $\begin{array}{l}\text { Stephens and } \\
\text { Tunney } \\
(2004)[37]\end{array}$ & $\begin{array}{l}8 \text { tests on } \\
\text { memory and } \\
\text { attention }\end{array}$ & $\begin{array}{l}\text { Sugar-free mint } \\
\text { flavored gum }\end{array}$ & $\begin{array}{l}\text { Improvements of scores on episode and working } \\
\text { memory, attention, and processing speed. No significant } \\
\text { differences in executive function. }\end{array}$ & Positive \\
\hline $\begin{array}{l}\text { Kohler et al. } \\
(2006) \text { [36] }\end{array}$ & $\begin{array}{l}\text { Psychomotor } \\
\text { vigilance, } \\
\text { tracking, and } \\
\text { grammatical } \\
\text { reasoning and } \\
\text { alertness }\end{array}$ & $\begin{array}{l}\text { Parafilm (sugar-free, } \\
\text { tasteless) }\end{array}$ & $\begin{array}{l}\text { Not significant or detrition of performance of speed and } \\
\text { accuracy on simple and complex cognitive tasks except } \\
\text { for a simple motor tracking task early during the period } \\
\text { of sleep deprivation. No significant differences in } \\
\text { alertness, heart rate, and root mean square of successive } \\
\text { differences in R-R intervals. }\end{array}$ & $\begin{array}{l}\text { Positive or negative } \\
\text { depending on task } \\
\text { and time }\end{array}$ \\
\hline $\begin{array}{l}\text { Sakamoto et } \\
\text { al. }(2009)[15]\end{array}$ & Reaction time & $\begin{array}{l}\text { Odorless and } \\
\text { tasteless gum base }\end{array}$ & $\begin{array}{l}\text { Shortening of reaction time and the peak latencies of } \\
\text { event-related potentials (P300 and N100) in second and } \\
\text { third session after chewing. }\end{array}$ & Positive \\
\hline $\begin{array}{l}\text { Smith (2009) } \\
{[16]}\end{array}$ & $\begin{array}{l}\text { Mood, alertness, } \\
\text { intelligence test, } \\
\text { and short term } \\
\text { and working } \\
\text { memory }\end{array}$ & $\begin{array}{l}\text { Volunteer's preferred } \\
\text { gum }\end{array}$ & $\begin{array}{l}\text { Improvement of intelligence test. No significant } \\
\text { difference in memory. Increased alertness at the end of } \\
\text { the test session. }\end{array}$ & Positive \\
\hline $\begin{array}{l}\text { Scholey et al. } \\
(2009)[21]\end{array}$ & $\begin{array}{l}4 \text { tests including } \\
\text { memory, } \\
\text { attention, and } \\
\text { mood }\end{array}$ & $\begin{array}{l}\text { Volunteer's preferred } \\
\text { gum }\end{array}$ & $\begin{array}{l}\text { Overall better performance on the cognitive tasks. } \\
\text { Increase of alertness and reduction of stress and salivary } \\
\text { cortisol. }\end{array}$ & Positive \\
\hline $\begin{array}{l}\text { Smith (2009) } \\
{[18]}\end{array}$ & $\begin{array}{l}5 \text { tests on } \\
\text { alertness and } \\
\text { mood }\end{array}$ & $\begin{array}{l}\text { Caffeinated gum or } \\
\text { placebo gum }\end{array}$ & $\begin{array}{l}\text { More positive mood after chewing and at the end of the } \\
\text { study regardless of caffeine. Higher alertness after } \\
\text { chewing. No significant difference in alertness without } \\
\text { caffeine. }\end{array}$ & Not significant \\
\hline $\begin{array}{l}\text { Sakamoto et } \\
\text { al. (2009) [14] }\end{array}$ & Reaction time & $\begin{array}{l}\text { Odorless and } \\
\text { tasteless gum base }\end{array}$ & $\begin{array}{l}\text { Shortened reaction time at third trials after chewing. } \\
\text { Increased contingent negative variation }(\mathrm{CNV}) \text { at second } \\
\text { and third trials after chewing. No significant differences } \\
\text { in movement-related control potentials. }\end{array}$ & Positive \\
\hline $\begin{array}{l}\text { Tänzer et al. } \\
(2009)[30]\end{array}$ & $\begin{array}{l}\text { 16-minute } \\
\text { concentration test }\end{array}$ & Sugar-free fruit gum & $\begin{array}{l}\text { Improvement of concentration performance with time in } \\
8 \text {-9-year-olds. }\end{array}$ & Positive \\
\hline $\begin{array}{ll}\text { Smith }(2010) \\
{[17]}\end{array}$ & $\begin{array}{l}10 \text { tests on } \\
\text { memory, } \\
\text { attention, and } \\
\text { mood }\end{array}$ & $\begin{array}{l}\text { Spearmint or fruit } \\
\text { gum }\end{array}$ & $\begin{array}{l}\text { Improvement of alertness and selective and sustained } \\
\text { attention. Shortened reaction time; this effect became } \\
\text { bigger as the task became more difficult. Increase of heart } \\
\text { rate and saliva cortisol. }\end{array}$ & Positive \\
\hline $\begin{array}{l}\text { Tucha et al. } \\
(2010)[42]\end{array}$ & $\begin{array}{l}\text { Vigilance and } \\
\text { sustained } \\
\text { attention }\end{array}$ & $\begin{array}{l}\text { Sugar-free } \\
\text { spearmint gum }\end{array}$ & $\begin{array}{l}\text { Deterioration of vigilance performance in both healthy } \\
\text { children and children with ADHD (mean age } 10.8 \text { years). } \\
\text { No significant difference in sustained attention. }\end{array}$ & Negative \\
\hline $\begin{array}{l}\text { Tucha and } \\
\text { Simpson } \\
(2011)[29]\end{array}$ & $\begin{array}{l}\text { Sustained } \\
\text { attention }\end{array}$ & $\begin{array}{l}\text { Sugar-free } \\
\text { spearmint gum }\end{array}$ & $\begin{array}{l}\text { Detriment on sustained attention in earlier stages of } \\
30 \text {-minute task and benefit on sustained attention at later } \\
\text { stages. }\end{array}$ & $\begin{array}{l}\text { Negative early to } \\
\text { positive later within } \\
\text { 30-min period }\end{array}$ \\
\hline $\begin{array}{l}\text { Johnson et al. } \\
\text { (2011) [25] }\end{array}$ & $\begin{array}{l}4 \text { tasks including } \\
\text { memory and } \\
\text { attention, mood, } \\
\text { and alertness }\end{array}$ & $\begin{array}{l}\text { Regular chewing } \\
\text { gum }\end{array}$ & $\begin{array}{l}\text { Increase of self-rated alertness and stress. No significant } \\
\text { differences in task performance and saliva cortisol. }\end{array}$ & Positive \\
\hline
\end{tabular}


TABle 1: Continued.

\begin{tabular}{|c|c|c|c|c|}
\hline Study & $\begin{array}{l}\text { Cognitive tests } \\
\text { and psychological } \\
\text { rating scales }\end{array}$ & Chewing objects & $\begin{array}{l}\text { Summary of results (compared with nonchewing } \\
\text { condition unless stated) }\end{array}$ & $\begin{array}{l}\text { Attributes of effects } \\
\text { on attention }\end{array}$ \\
\hline $\begin{array}{l}\text { Onyper et al. } \\
(2011)[41]\end{array}$ & $\begin{array}{l}5 \text { tasks including } \\
\text { memory and } \\
\text { attention }\end{array}$ & $\begin{array}{l}\text { Spearmint or } \\
\text { doublemint gum } \\
\text { with or without } \\
\text { sugar }\end{array}$ & $\begin{array}{l}\text { Improvements of performance of several tasks in } \\
\text { chewing for } 5 \text { minutes prior to testing. No significant } \\
\text { differences in chewing throughout testing. }\end{array}$ & $\begin{array}{l}\text { Positive in chewing } \\
\text { prior to testing }\end{array}$ \\
\hline $\begin{array}{l}\text { Sketchley- } \\
\text { Kaye et al. } \\
(2011)[26]\end{array}$ & $\begin{array}{l}\text { Acute stress task, } \\
\text { mood, anxiety, } \\
\text { and alertness }\end{array}$ & $\begin{array}{l}\text { Regular chewing } \\
\text { gum }\end{array}$ & $\begin{array}{l}\text { Attenuation of state anxiety and increase of alertness } \\
\text { under condition of acute social stress task. No significant } \\
\text { differences in contentedness or calmness. }\end{array}$ & Positive \\
\hline $\begin{array}{l}\text { Allen and } \\
\text { Smith (2012) } \\
{[31]}\end{array}$ & $\begin{array}{l}4 \text { tasks on } \\
\text { attention and } \\
\text { mood }\end{array}$ & $\begin{array}{l}\text { Volunteer's preferred } \\
\text { gum }\end{array}$ & $\begin{array}{l}\text { Increased alertness, mood, and performance of attention } \\
\text { test and shortened reaction time. Initial extended } \\
\text { vigilance reaction times were shortened after trials. }\end{array}$ & $\begin{array}{l}\text { Positive, but some } \\
\text { tests showed negative } \\
\text { effects initially }\end{array}$ \\
\hline $\begin{array}{l}\text { Allen and } \\
\text { Smith (2012) } \\
{[38]}\end{array}$ & $\begin{array}{l}4 \text { tasks on } \\
\text { attention and } \\
\text { mood }\end{array}$ & $\begin{array}{l}\text { Volunteer's preferred } \\
\text { gum }\end{array}$ & $\begin{array}{l}\text { Increased reported alertness for positive and neutral } \\
\text { demand characteristics. Improved selective attention. } \\
\text { Reduced performances of two attention tasks only at } \\
\text { specific time of trials. Better response organization on } \\
\text { categoric search task when demand characteristics and } \\
\text { pretest attitudes to gum were both negative. }\end{array}$ & $\begin{array}{l}\text { Positive, but some } \\
\text { tests showed negative } \\
\text { effects at specific time } \\
\text { of trials }\end{array}$ \\
\hline $\begin{array}{l}\text { Hirano et al. } \\
(2013)[12]\end{array}$ & $\begin{array}{l}\text { Alerting and } \\
\text { executive control }\end{array}$ & $\begin{array}{l}\text { Odorless and } \\
\text { tasteless gum base }\end{array}$ & $\begin{array}{l}\text { Shortened reaction time. No significant differences in } \\
\text { alerting and conflict effects. Higher activations in the } \\
\text { anterior cingulate cortex and left frontal gyrus for the } \\
\text { executive network and motor-related regions for both } \\
\text { attentional networks }\end{array}$ & Positive \\
\hline $\begin{array}{l}\text { Johnson et al. } \\
\text { (2013) [28] }\end{array}$ & $\begin{array}{l}\text { Sustained } \\
\text { attention, } \\
\text { alertness, and } \\
\text { mood }\end{array}$ & Cool Breeze gum & $\begin{array}{l}\text { Improved attentional task performance. Higher alertness } \\
\text { and mood. Shortened response times. No time-on-task } \\
\text { effect. }\end{array}$ & Positive \\
\hline $\begin{array}{l}\text { Morgan et al. } \\
(2014)[32]\end{array}$ & $\begin{array}{l}\text { Short-term } \\
\text { memory, } \\
\text { vigilance, and } \\
\text { mood }\end{array}$ & $\begin{array}{l}\text { Sugar-free } \\
\text { spearmint gum }\end{array}$ & $\begin{array}{l}\text { Attenuated time-dependent decrement on both } \\
\text { performance and subjective alertness. Shorter correct } \\
\text { reaction time in the latter stage of the task. }\end{array}$ & $\begin{array}{l}\text { Positive, especially in } \\
\text { the latter stage of the } \\
\text { task }\end{array}$ \\
\hline $\begin{array}{l}\text { Allen et al. } \\
(2014)[35]\end{array}$ & $\begin{array}{l}\text { Vigilance and } \\
\text { mood }\end{array}$ & Gum base & $\begin{array}{l}\text { Shortened reaction time and increased rate of hits. } \\
\text { Heightened heart rate during chewing. Increased EEG } \\
\text { beta power at F7 and T3 immediately after chewing. }\end{array}$ & Positive \\
\hline
\end{tabular}

times were significantly shorter in the latter stages of the task, in addition to the decline in both performance and subjective alertness in the chewing gum group. Johnson et al. [28] also reported the existence of time-on-task effect and initial impairment of attention. Tucha and Simpson [29] speculated that participants might be distracted by dual task interference [33] induced by gum chewing during early stages of cognitive tasks or that certain biological processes (e.g., increase of regional cerebral blood flow) have to add up or reach a certain threshold to facilitate cognitive processing. In this view, as a result of the study, the better performance of working memory task in chewing condition at the last stage could be explained [13].

The mechanisms of the beneficial effects of chewing on attention have been discussed for a long time, and they have been estimated as being derived from increases of cerebral blood flow and brain activity $[12,24,27]$, cerebral blood flow $[23,34]$, cardiovascular system $[10,17,35,36]$, ascending reticular activating system [14, 15], glucose delivery [37], and flavors [11]. Recently, Hasegawa et al. [34] assumed that taste and odor can influence brain activation during chewing in sensory, cognitive, and motivational processes rather than in motor control, although some studies confirmed the beneficial effects on attention with tasteless and odorless gum base [12, 14, 15]. Allen and Smith [38] reported that a benefit for alertness was shown in persons with positive and neutral demand characteristics, but a positive effect on response organization was observed with demand characteristics [39] and the pretest attitude to gum. More recently, Yu et al. [40] demonstrated an fMRI study showing that gum chewing inhibited functional connectivity between the left anterior insular and the dorsal anterior cingulate cortex and functional connectivity from the superior temporal sulcus to the left anterior insula when activated by noise. They stated that gum chewing relieves stress by attenuating the sensory processing of external stressor and by inhibiting the propagation of stress-related information in the brain stress network. Allen et al. [35] reported that chewing can alter central and sympathetic nervous system activity associated with vigilance performance. The transient effect in their study was consistent with the short-lived effect of chewing gum on hits in the vigilance task. 
In conclusion, many of the studies indicated that chewing exerts a positive effect on attention, and especially on sustained attention, in addition to improved mood and stress relief. Also, the effect seems to be influenced by time-on-task effect and do not last so long, such as 15-20 [41] or more than 30 minutes [29] after chewing, and then the mechanisms of the effects were not yet fully elucidated. Further studies are needed, but chewing could be useful as an easy method for modifying cognitive function on a daily basis and not be demanding physically and mentally.

\section{Conflict of Interests}

The authors declare that they have no conflict of interests regarding the publication of this paper.

\section{References}

[1] H. Abekura, M. Tsuboi, T. Okura, K. Kagawa, S. Sadamori, and Y. Akagawa, "Association between sleep bruxism and stress sensitivity in an experimental psychological stress task," Biomedical Research, vol. 32, no. 6, pp. 395-399, 2011.

[2] R. A. Hicks and P. Conti, "Nocturnal bruxism and self reports of stress-related symptoms," Perceptual and Motor Skills, vol. 72, no. 3, part 2, p. 1182, 1991.

[3] R. Stewart, R. J. Weyant, M. E. Garcia et al., "Adverse oral health and cognitive decline: the health, aging and body composition study," Journal of the American Geriatrics Society, vol. 61, no. 2, pp. 177-184, 2013.

[4] Y. Takata, T. Ansai, I. Soh et al., "Cognitive function and number of teeth in a community-dwelling elderly population without dementia," Journal of Oral Rehabilitation, vol. 36, no. 11, pp. 808$813,2009$.

[5] Y. Hirano and M. Onozuka, "Chewing and cognitive function," Brain and Nerve, vol. 66, no. 1, pp. 25-32, 2014.

[6] H. L. Hollingworth, "Chewing as a technique of relaxation," Science, vol. 90, no. 2339, pp. 385-387, 1939.

[7] Y. Masumoto, T. Morinushi, H. Kawasaki, and M. Takigawa, "Spectral analysis of changes in electroencephalographic activity after the chewing of gum," Psychiatry and Clinical Neurosciences, vol. 52, no. 6, pp. 587-592, 1998.

[8] Y. Masumoto, T. Morinushi, H. Kawasaki, T. Ogura, and M. Takigawa, "Effects of three principal constituents in chewing gum on electroencephalographic activity," Psychiatry and Clinical Neurosciences, vol. 53, no. 1, pp. 17-23, 1999.

[9] T. Morinushi, Y. Masumoto, H. Kawasaki, and M. Takigawa, "Effect on electroencephalogram of chewing flavored gum," Psychiatry and Clinical Neurosciences, vol. 54, no. 6, pp. 645-651, 2000.

[10] L. Wilkinson, A. Scholey, and K. Wesnes, "Chewing gum selectively improves aspects of memory in healthy volunteers," Appetite, vol. 38, no. 3, pp. 235-236, 2002.

[11] O. Tucha, L. Mecklinger, K. Maier, M. Hammerl, and K. W. Lange, "Chewing gum differentially affects aspects of attention in healthy subjects," Appetite, vol. 42, no. 3, pp. 327-329, 2004.

[12] Y. Hirano, T. Obata, H. Takahashi et al., "Effects of chewing on cognitive processing speed," Brain and Cognition, vol. 81, no. 3, pp. 376-381, 2013.

[13] Y. Hirano, T. Obata, K. Kashikura et al., "Effects of chewing in working memory processing," Neuroscience Letters, vol. 436, no. 2, pp. 189-192, 2008.
[14] K. Sakamoto, H. Nakata, Y. Honda, and R. Kakigi, "The effect of mastication on human motor preparation processing: a study with CNV and MRCP," Neuroscience Research, vol. 64, no. 3, pp. 259-266, 2009.

[15] K. Sakamoto, H. Nakata, and R. Kakigi, “The effect of mastication on human cognitive processing: a study using event-related potentials," Clinical Neurophysiology, vol. 120, no. 1, pp. 41-50, 2009.

[16] A. Smith, "Effects of chewing gum on mood, learning, memory and performance of an intelligence test," Nutritional Neuroscience, vol. 12, no. 2, pp. 81-88, 2009.

[17] A. Smith, "Effects of chewing gum on cognitive function, mood and physiology in stressed and non-stressed volunteers," Nutritional Neuroscience, vol. 13, no. 1, pp. 7-16, 2010.

[18] A. Smith, "Effects of caffeine in chewing gum on mood and attention," Human Psychopharmacology, vol. 24, no. 3, pp. 239247, 2009.

[19] W. Waterink and A. van Boxtel, "Facial and jaw-elevator EMG activity in relation to changes in performance level during a sustained information processing task," Biological Psychology, vol. 37, no. 3, pp. 183-198, 1994.

[20] Y. Mohri, M. Fumoto, I. Sato-Suzuki, M. Umino, and H. Arita, "Prolonged rhythmic gum chewing suppresses nociceptive response via serotonergic descending inhibitory pathway in humans," Pain, vol. 118, no. 1-2, pp. 35-42, 2005.

[21] A. Scholey, C. Haskell, B. Robertson, D. Kennedy, A. Milne, and M. Wetherell, "Chewing gum alleviates negative mood and reduces cortisol during acute laboratory psychological stress," Physiology \& Behavior, vol. 97, no. 3-4, pp. 304-312, 2009.

[22] L. E. Spieker, D. Hürlimann, F. Ruschitzka et al., "Mental stress induces prolonged endothelial dysfunction via endothelin-a receptors," Circulation, vol. 105, no. 24, pp. 2817-2820, 2002.

[23] T. Momose, J. Nishikawa, T. Watanabe et al., "Effect of mastication on regional cerebral blood flow in humans examined by positron-emission tomography with ${ }^{15} \mathrm{O}$-labelled water and magnetic resonance imaging," Archives of Oral Biology, vol. 42, no. 1, pp. 57-61, 1997.

[24] M. Onozuka, M. Fujita, K. Watanabe et al., "Mapping brain region activity during chewing: a functional magnetic resonance imaging study," Journal of Dental Research, vol. 81, no. 11, pp. 743-746, 2002.

[25] A. J. Johnson, R. Jenks, C. Miles, M. Albert, and M. Cox, "Chewing gum moderates multi-task induced shifts in stress, mood, and alertness. A re-examination," Appetite, vol. 56, no. 2, pp. 408-411, 2011.

[26] K. Sketchley-Kaye, R. Jenks, C. Miles, and A. J. Johnson, "Chewing gum modifies state anxiety and alertness under conditions of social stress," Nutritional Neuroscience, vol. 14, no. 6, pp. 237242, 2011.

[27] M. Fang, J. Li, G. Lu, X. Gong, and D. T. Yew, "A fMRI study of age-related differential cortical patterns during cued motor movement," Brain Topography, vol. 17, no. 3, pp. 127-137, 2005.

[28] A. J. Johnson, M. Muneem, and C. Miles, "Chewing gum benefits sustained attention in the absence of task degradation," Nutritional Neuroscience, vol. 16, no. 4, pp. 153-159, 2013.

[29] L. Tucha and W. Simpson, "The role of time on task performance in modifying the effects of gum chewing on attention," Appetite, vol. 56, no. 2, pp. 299-301, 2011.

[30] U. Tänzer, A. von Fintel, and T. Eikermann, "Chewing gum and concentration performance," Psychological Reports, vol. 105, no. 2, pp. 372-374, 2009. 
[31] A. P. Allen and A. P. Smith, "Effects of chewing gum and timeon-task on alertness and attention," Nutritional Neuroscience, vol. 15, no. 4, pp. 176-185, 2012.

[32] K. Morgan, A. J. Johnson, and C. Miles, "Chewing gum moderates the vigilance decrement," The British Journal of Psychology, vol. 105, no. 2, pp. 214-225, 2014.

[33] K. Lambourne and P. Tomporowski, "The effect of exerciseinduced arousal on cognitive task performance: a meta-regression analysis," Brain Research, vol. 1341, pp. 12-24, 2010.

[34] Y. Hasegawa, Y. Tachibana, J. Sakagami, M. Zhang, M. Urade, and T. Ono, "Flavor-enhanced modulation of cerebral blood flow during gum chewing," PLoS ONE, vol. 8, no. 6, Article ID e66313, 2013.

[35] A. P. Allen, T. J. C. Jacob, and A. P. Smith, "Effects and aftereffects of chewing gum on vigilance, heart rate, EEG and mood," Physiology \& Behavior, vol. 133, pp. 244-251, 2014.

[36] M. Kohler, A. Pavy, and C. van den Heuvel, "The effects of chewing versus caffeine on alertness, cognitive performance and cardiac autonomic activity during sleep deprivation," Journal of Sleep Research, vol. 15, no. 4, pp. 358-368, 2006.

[37] R. Stephens and R. J. Tunney, "Role of glucose in chewing gumrelated facilitation of cognitive function," Appetite, vol. 43, no. 2, pp. 211-213, 2004.

[38] A. P. Allen and A. P. Smith, "Demand characteristics, pre-test attitudes and time-on-task trends in the effects of chewing gum on attention and reported mood in healthy volunteers," Appetite, vol. 59, no. 2, pp. 349-356, 2012.

[39] M. T. Orne, "On the social psychology of the psychological experiment: with particular reference to demand characteristics and their implications," The American Psychologist, vol. 17, no. 11, pp. 776-783, 1962.

[40] H. Yu, X. Chen, J. Liu, and X. Zhou, "Gum chewing inhibits the sensory processing and the propagation of stress-related information in a brain network," PLoS ONE, vol. 8, no. 4, Article ID e57111, 2013.

[41] S. V. Onyper, T. L. Carr, J. S. Farrar, and B. R. Floyd, "Cognitive advantages of chewing gum. Now you see them, now you don't," Appetite, vol. 57, no. 2, pp. 321-328, 2011.

[42] L. Tucha, W. Simpson, L. Evans et al., "Detrimental effects of gum chewing on vigilance in children with attention deficit hyperactivity disorder," Appetite, vol. 55, no. 3, pp. 679-684, 2010. 

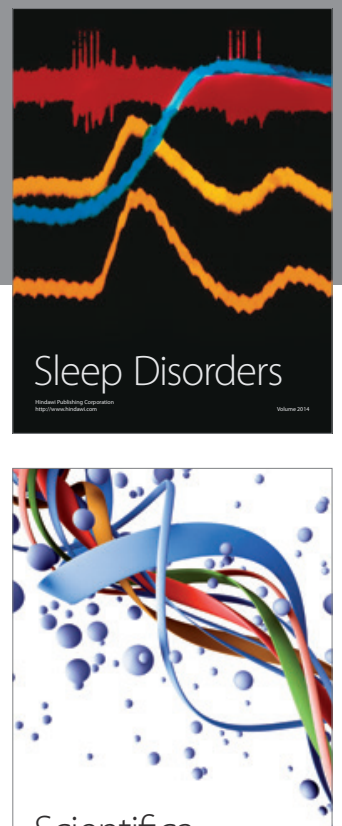

Scientifica
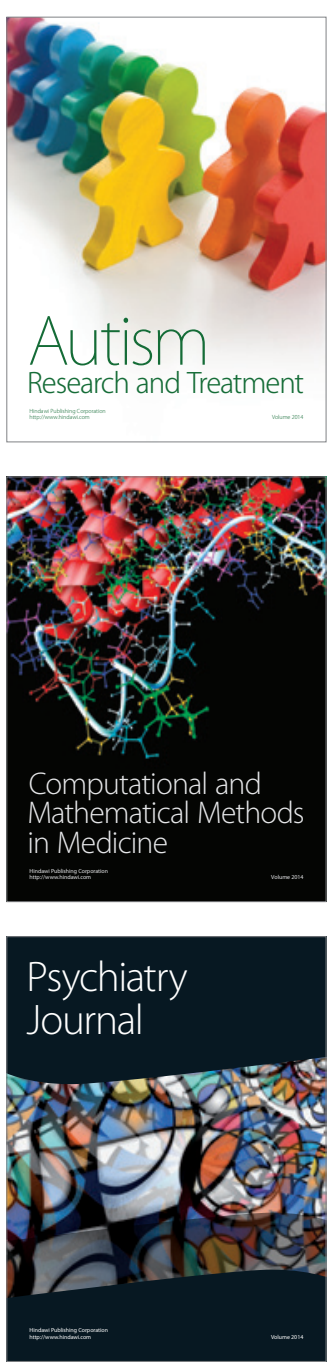
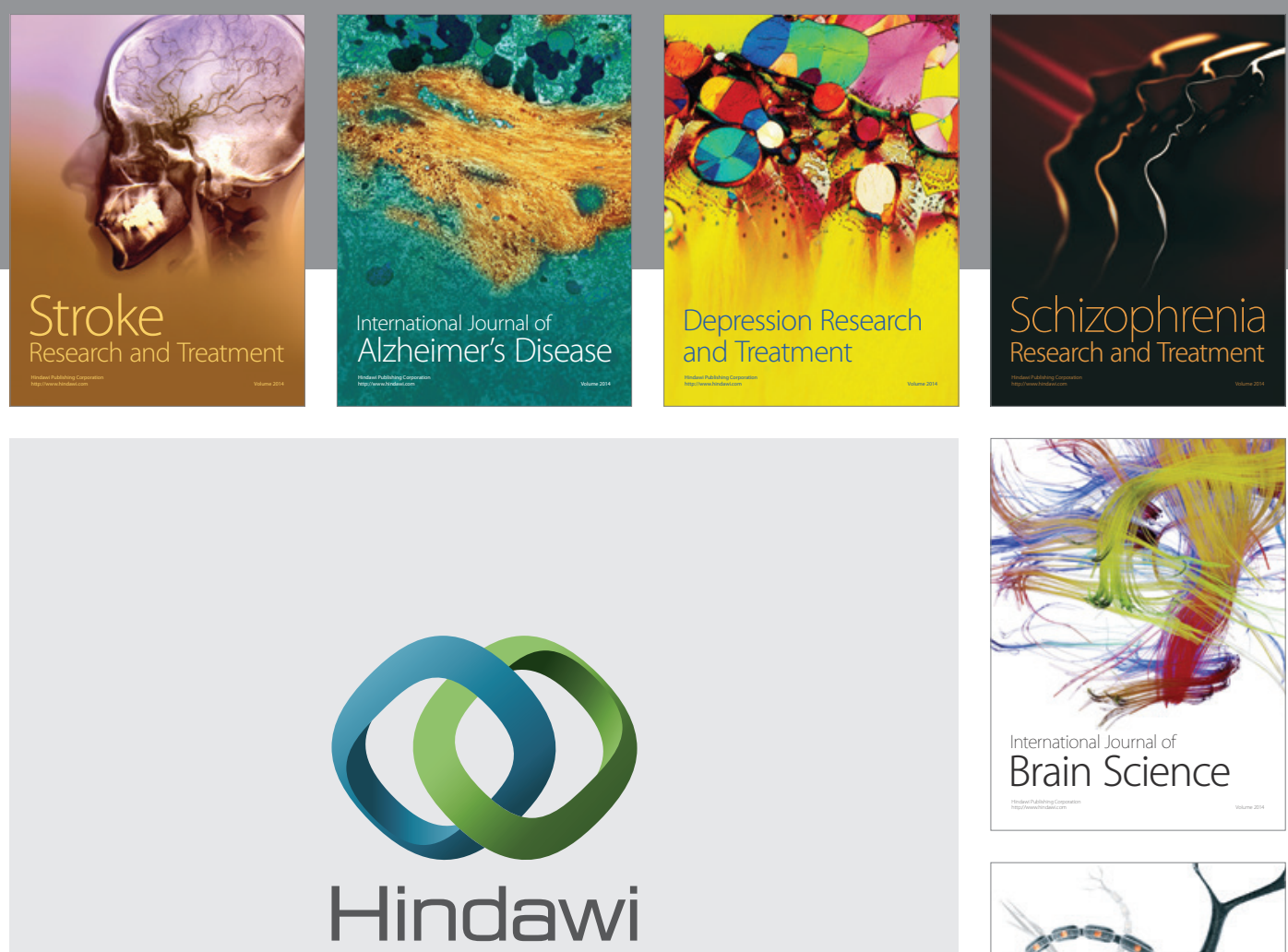

Submit your manuscripts at

http://www.hindawi.com
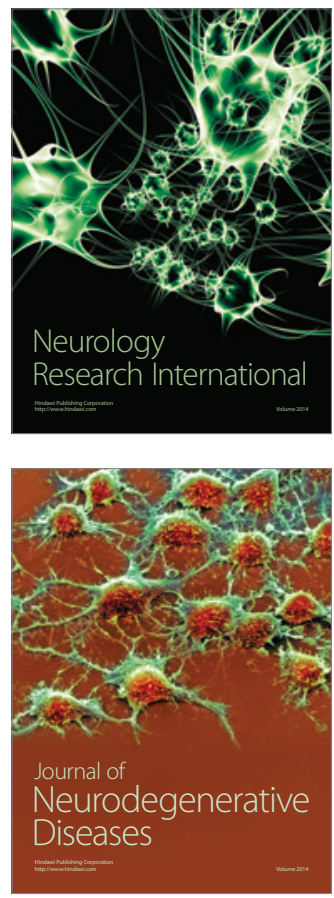

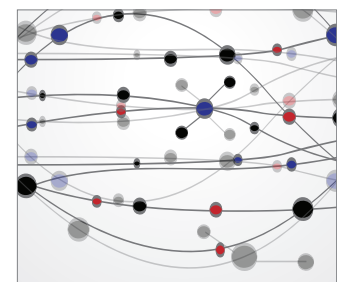

The Scientific World Journal
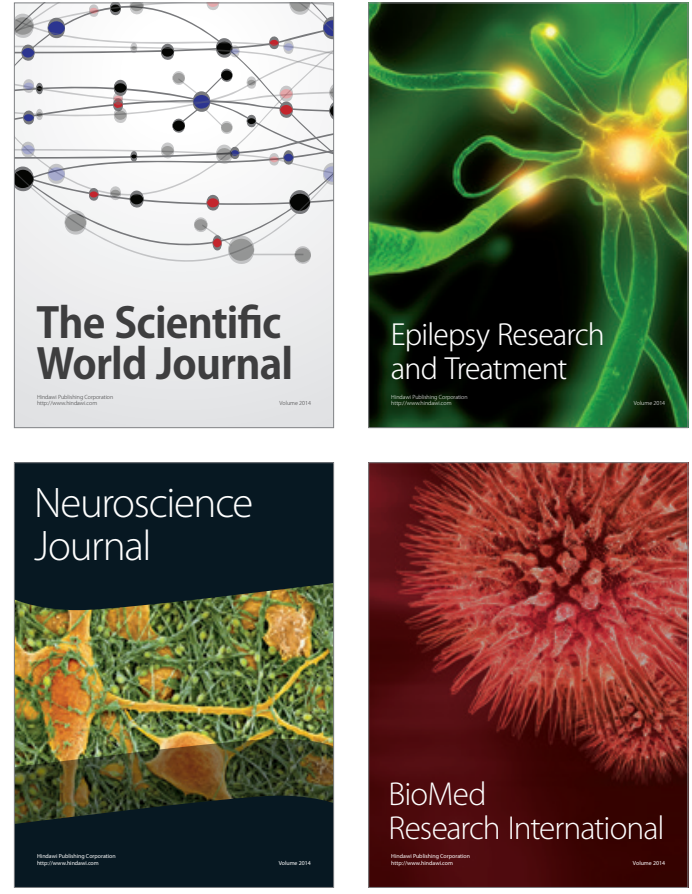

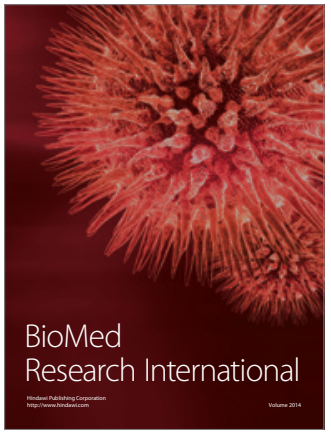

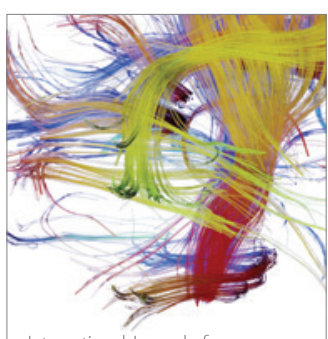

Brain Science

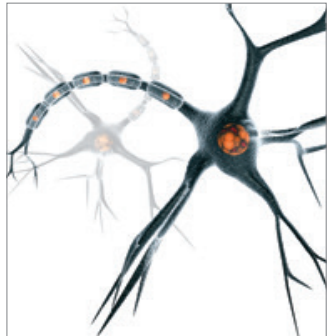

Neural Plasticity
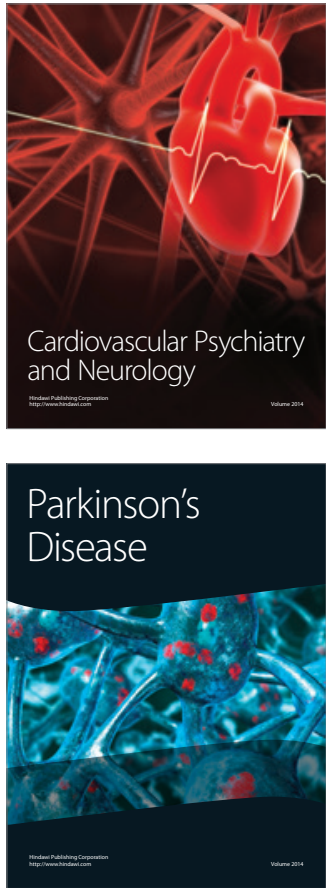